\title{
JURIANAI
}

Jurnal Pendidikan Ekonomi

$\therefore$ JUR KAIMI

VOLLME

5
NOMOR

2

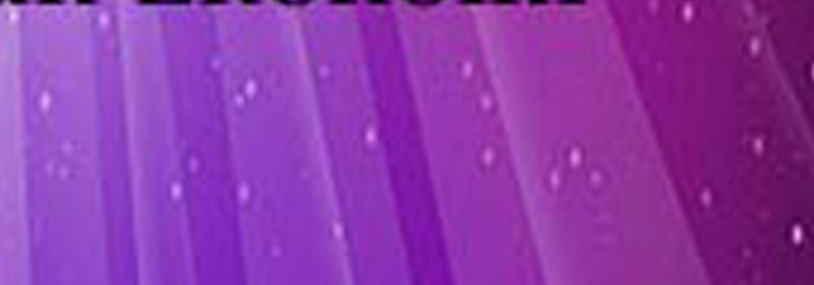




\title{
JURKAMI: Jurnal Pendidikan Ekonomi \\ http://jurnal.stkippersada.ac.id/jurnal/index.php/JPE \\ JURKAMI Volume 5, no 2, 2020
}

\section{ANALISIS PERTUMBUHAN EKONOMI DAN PENGEMBANGAN WILAYAH PERBATASAN ENTIKONG}

\author{
Kardius Richi Yosada
}

STKIP Persada Khatulistiwa Sintang, Indonesia

Email: richiyosada78@gmail.com

Diterima: 23 Oktober 2020; Disetujui: 29 Oktober 2020; Diterbitkan: 1 November 2020

Abstract: The existing economic wealth and other non-economic advantages are also a driving factor for improving the socio-economic welfare of the people around the Entikong border area. In addition to having interrelationships that influence each other with activities carried out in other border areas, as well as having an impact on defense and security conditions both on a regional and national scale. The achievement of increasing the welfare of the people in the Entikong border area can also be determined by the dynamics of how cooperative the cross-regional collaboration is and the degree of involvement of community groups, local governments, Regional-Owned Enterprises (BUMD), the private sector and legal institutions. The average economic growth rate compared to the population growth rate From the results of the analysis carried out, the average economic growth rate in Entikong District reached $5.88 \%$ which was higher than the population growth rate, namely $1.18 \%$. This condition reflects economic growth, where the rate of economic growth is higher than the population growth rate. The economic contribution of Entikong Subdistrict to Sanggau Regency was $2.32 \%$ on average (2009-2013), with a relatively declining condition since 2009.

\section{Keywords: Economic Growth, Development Border Area, Entikong}

Abstrak: Kekayaan ekonomi dan keunggulan non ekonomi lainnya yang ada juga merupakan faktor pendorong bagi peningkatan kesejahteraan sosial ekonomi masyarakat di sekitar wilayah perbatasan Entikong, disamping mempunyai keterkaitan yang saling mempengaruhi dengan kegiatan yang dilaksanakan di wilayah lainnya yang berbatasan antar wilayah maupun antar negara, serta mempunyai dampak terhadap kondisi pertahanan dan keamanan baik dalam skala regional maupun nasional. Keberhasilan pencapaian peningkatan kesejahteraan masyarakat wilayah perbatasan Entikong juga dapat ditentukan oleh dinamika seberapa kooperatif kolaborasi lintas wilayah dan derajat keterlibatan kelompok masyarakat, pemerintah daerah, Badan Usaha Milik Daerah (BUMD), sektor swasta dan lembaga hukum laju pertumbuhan ekonomi rata-rata dibandingkan dengan laju pertumbuhan penduduk Dari hasil analisis yang dilakukan, laju pertumbuhan ekonomi rata-rata di Kecamatan Entikong mencapai angka 5,88\% yang lebih tinggi dari angka laju pertumbuhan penduduk, yaitu $1,18 \%$. Kondisi tersebut mencerminkan adanya pertumbuhan ekonomi, karena laju pertumbuhan ekonomi lebih tinggi dari laju pertumbuhan penduduk. Kontribusi ekonomi yang dimiliki oleh Kecamatan Entikong terhadap Kabupaten Sanggau rata-rata sebesar 2,32\% (tahun 2009-2013), dengan kondisi yang relatif menurun sejak tahun 2009.

\section{Kata Kunci: Pertumbuhan Ekonomi, Pengembangan Wilayah Perbatasan, Entikong}




\section{PENDAHULUAN}

Wilayah perbatasan suatu negara memiliki peran penting dalam penentuan batas wilayah kedaulatan, pemanfaatan sumber daya alam, menjaga keamanan dan keutuhan wilayah. Pembangunan wilayah perbatasan pada dasarnya merupakan bagian integral dari pembangunan nasional. Wilayah perbatasan mempunyai nilai strategis dalam mendukung keberhasilan pembangunan nasional, hal tersebut ditunjukkan oleh karakteristik kegiatan yang mempunyai dampak penting bagi kedaulatan negara, menjadi faktor pendorong bagi peningkatan kesejahteraan sosial ekonomi masyarakat sekitarnya, memiliki keterkaitan yang saling mempengaruhi dengan kegiatan yang dilaksanakan di wilayah lainnya yang berbatasan dengan wilayah maupun antar negara, serta mempunyai dampak terhadap kondisi pertahanan dan keamanan, baik skala regional maupun nasional (BKPM, 2011).

Peningkatan pergerakan disebabkan oleh berubahnya fungsi pos pelintas batas yang tidak hanya dilalui oleh pelintas tradisional tetapi disebabkan pula oleh pelintas non tradisional (Kurniadi, 2009).

\section{KAJIAN TEORI}

Menurut Hamid (2003), kawasan perbatasan antarnegara merupakan kawasanyang strategis karena merupakan titik tumbuh bagi perekonomian regional maupun nasional. Melalui kawasan ini, kegiatan perdagangan antarnegara dapat dilakukandengan mudah, cepat dan murah yang pada gilirannya akan mendorong naiknya aktivitas produksi masyarakat, pendapatan masyarakat dan berujung pada kesejahteraan masyarakat.

a. Konsep Wilayah

Wilayah itu dibedakan berdasarkan musim/temperatur yang dimilikinya atau berdasarkan konfigurasi lahan, jenis tumbuh-tumbuhan, kepadatan penduduk, atau gabungan dari ciri-ciri diatas. Menggunakan pandangan obyektif membuat analisis ruang menjadi terbatas.Dalam melakukan studi mengenai pengembangan wilayah, khususnya tentang wilayah perbatasan antar negara (transborder region), hal yang perlu dijelaskan adalah beberapa konsep tentang wilayah (region) itu sendiri. John Glasson (1974:37) mengemukakan konsep tentang wilayah sebagai metode klasifikasi yang muncul melalui dua hal yang berbeda, yaitu yang mencerminkan kemajuan ekonomi dariperekonomian sederhana ke sistem industri yang kompleks.Pada fase pertama memperlihatkan wilayah formal yaitu berkenaan dengan keseragaman dan didefinisikan menurut homogenitas. Fase kedua memperlihatkan perkembangan wilayah fungsional yaitu berkenaan dengan interdependensi, saling hubungan 
antara bagian-bagian dan didefinisikan menurut koherensi fungsional.

Wilayah formal adalah wilayah geografik yang seragam atau homogenya menurut kriteria tertentu.Pada awalnya kriteria yang digunakan untuk mendefinisikan wilayah formal, terutama adalah bersifat fisik seperti topografi, iklimdan vegetasi dikaitkan dengan konsep determinasi geografik. Tetapi berikutnya terjadi peralihan kepada penggunaan kriteria ekonomi, seperti tipe industri atau tipe pertanian.Wilayah alamiah adalah wilayah formal fisik (Husnadi, 2006).

Wilayah fungsional adalah wilayah geografik yang memperlihatkan suatu koherensi fungsional tertentu, suatu interdependensi dari bagian-bagian, bila didefinisikan berdasarkan kriteria tertentu. Wilayah fungsional ini kadang-kadang disebut sebagai wilayah Nodal atau polarized region dan terdiri dari satuansatuanyang heterogen, seperti desa-kota yang secara fungsional saling berdekatan (Husnadi, 2006). Wilayah formal atau wilayah fungsional ataupun gabungan keduanya memberikan suatu kerangka bagi klasifikasi tipe wilayah yang ketiga yaitu wilayah perencanaan.Wilayah perencanaan merupakan wilayah geografik yang cocok untuk perencanaan dan pelaksanaan rencana-rencana pembangunan untuk memecahkan persoalan-persoalan wilayah.
Jika pengertian wilayah formal (homogen) dan wilayah fungsional (polarized) digabungkan dengan perencanaan, dapat dikenal dua macam pendekatan dalam perencanaan wilayah (Jayadinata, 1999:16) yaitu:

pendekatan teritorial untuk perencanaan suatu wilayah formal. Menurut Friedmann dan Weaver, perencanaan suatu wilayah formal dengan pendekatan teritorial tersebut memperhitungkan mobilisasi terpadu dari semua sumber daya manusia dan sumber daya alam dari suatu wilayah tertentu yang dicirikan oleh perkembangan sejarahnya, karena sejarah adalah salah satu yang dapat mengikat anggota masyarakat suatu wilayah territorial, sehingga dapat terbentuk beberapa kelompok sosial seperti suku dan bangsa. Perencanaan semacam itu dapat disebut perencanaan wilayah teritorial atau perencanaanwilayah formal (2) pendekatan fungsional, yaitu suatu perencanaan wilayah yang menurut Friedmann dan Weaver, memperhitungkan lokasi berbagai kegiatan ekonomi dan pengaturan secara ruang dari sistem perkotaan mengenai berbagai pusat dan jaringan. Perencanaan ini dapat disebut sebagai perencanaan wilayah fungsional, seperti kelompok sosial yang membentuk khas fungsional terikat oleh kepentingan, seperti misalnya kelas sosial, perserikatan dagang, dan sebagainya. 
b. Paradigma Baru Pengembangan Wilayah

Seiring dengan proses globalisasi saat ini, kota-kota besar maupun kawasankawasan strategis di Indonesia akan berkembang menjadi sebuah sistem kewilayahan dimana satu sama lain akan terikat dalam suatu sistem keseimbangan dan saling ketergantungan (complementarity and interdependency).

Globalisasi danregionalisasi tidak saja menyebabkan terjadinya perubahan dan dinamika sosial,spasial, dan ekonomi diantara dua kota metropolitan, tetapi dalam beberapa kasusjuga berlangsung pada kota-kota kedua (secondary urban cities), terutama di daerahyang sedang mengalami percepatan proses industrialisasi (Riyadi, 2002:3).

Peningkatan kawasan transborder (perbatasan antar negara) sebagai bagian dari perubahan geografi ekonomi dan wilayah (termasuk tenaga kerja/buruh) dalam skala global dihasilkan melalui proses globalisasi dan integrasi internasional. Kawasan ini disebut simply border regions (Gonzalez, 2001). Menurut Gonzalez (2001:59), menjelaskan bahwa kemunculan kawasan perbatasan antar negara (transborder region) sebagai ketika kekuatanpasar melebihi hambatan konvensional yang dihasilkan oleh manusia dan dinamika ekonomi, menginduksi sebuah evolusi, solidaritas dan konvergensi di dua sisi perbatasan, dimana sebuah ruang transisi terbentuk diantara mereka atau dengan kata lain sebuah kawasan ketiga dengan semua hal menarik yang melingkupi proses pencangkokan, hal ini disebut juga sebagai cross fertilization. Pelaku tidak hanya merubah tetapi juga membawa pengaruh budaya yang baru atau identitas ruangbudaya yang baru dari kawasan yang bersebelahan. Gagasan serupa ialah kawasan ekonomi transnasional, dimana masyarakat, perusahaan dan pemerintahan saling berinteraksi dan mengorganisasikan diri untuk kemudian secara bersama-sama mengatur regional action dan peningkatan pengembangan ekonomi, perencanaan transportasi, serta inisiatif lainnya. Hubungan transborder tersebut dapat terdiri dari bermacam-macam aspek fungsional dengan tingkat kerjasama yang lebih formal dan intensif.

c. Tipologi Kawasan Perbatasan

Tipologi yang diadopsi dari pemikiran Wu (2001:21-24) pada dasarnya adalah sebuah klasifikasi karakteristik dari pengembangan kawasan perbatasan, sehingga setiap tahapan pengembangan dapat diidentifikasi. Klasifikasi bertujuan meningkatkan studi komparatif dengan mengelompokkan karakteristik proses timbulnya pengembangan kawasan perbatasan dan menggambarkan proses pengembangan ke tahap selanjutnya. 
152 | Kardius Richi Yosada, Analisis Pertumbuhan Ekonomi dan Pengembangan Wilayah

Menurut Ratti (1993), pengembangan kawasan perbatasan merupakan sebuah rangkaian proses pergerakan yang semula dari daerah perbatasan (frontier) sebagai sebuah barrier (rintangan), menjadi suatu kawasan perbatasan sebagai filter, kemudian membentuk kawasan perbatasan sebagai sebuah zona kontak.

Tiga jenis/tipe pengembangan kawasan perbatasan yang dianjurkan oleh tipologi ini bertujuan mengelompokkan karakteristik eksisting pada pengembangan kawasan perbatasan dan mengidentifikasi hambatan-hambatan kunci dan isu kebijakan yang menuntut perhatian lebih besar jika pengembangan yang lebih majuakan dilakukan pada tahapan berikutnya (Husnadi, 2006).

\section{METODOLOGI PENELITIAN}

Pendekatan yang digunakan dalam penelitian ini adalah kualitatif fenomenologi dengan Existing Models. Pendekatan kualitatif digunakan karena data yang akan dikumpulkan bersifat data lunak (soft), penekanan pada deskripsideskripsi tentang orang, tempat dan percakapan dan tidak menekankan penggunaan prosedur statistik. Fenomenologi digunakan karena penelitian ini berusaha untuk menggambarkan dan masuk ke dalam dunia konseptual subyek guna mendapatkan pemahaman yang lebih dalam mengenai bagaimana dan apa makna yang disusun subyek di sekitar kejadian-kejadian dalam kehidupan kesehariannya. Pendekatan kualitatif fenomenologi merupakan cara pendekatan yang menekankan pada kondisi alami (naturalistic), kerja lapangan, dan instrumen utamanya adalah peneliti itu sendiri dan lebih banyak pengungkapan bersifat deskriptif. Adapun yang menjadi pusat perhatian adalah fenomenafenomena yang tampak maupun gejalagejala yang melatarbelakanginya berdasarkan pemahaman subyektif dari peneliti itu. Sedangkan metode penelitian yang peneliti gunakan dalam penelitian ini adalah deskriptif kualitatif yang merupakan penggambaran peristiwa pada saat itu, pendekatan penelitian ini sesuai dengan karakteristik penelitian kualitatif sebagaimana yang dikemukan oleh Bogdan dan Biklen (1992:29-32), yaitu:

1. Latar penelitian sebagai sumber data bersifat alamiah dan peneliti berperan sebagai instrumen utama.

2. Bersifat deskriptif

3. Lebih menekankan pada proses daripada hasil

4. Data yang dianalisis bersifat induktif

5. Pemaknaan dalam konteks menjadi perhatian utama

Analisis dalam penelitian ini menggunakan model interaktif dengan komponen-komponen antara lain: 
pengumpulan data, reduksi data, kesimpulan-kesimpulan yang merupakan penarikan/verifikasi data dan penyajian data (Matthew B Milles, dan A Michael Huberman, 1992:20

\section{HASIL DAN PEMBAHASAN}

Berdasarkan analisis spasial yang dilakukan sebelumnya, menjelaskan adanya perubahan penggunaan lahan, struktur ruang dan kependudukan yang mengindikasikan tumbuhnya aktivitas ekonomi di Kecamatan Entikong (Niebuhr dan Stiller; 2001; Soekanto, 2003; Branch, 1995). Perubahan spasial tersebut menunjukkan adanya kecenderungan perubahan guna lahan bagi permukiman $(0,15 \%)$, polarisasi penduduk yang berada di desa Entikong (kepadatan yang paling tinggi) dan terbentuknya pola linier dalam perkembangan kawasan mengikuti jalan arteri (ribbon development).

Berdasarkan tinjauan secara teoritis dan empiris, maka kondisi diatas menunjukan adanya pertumbuhan ekonomi kawasan sesuai dengan fungsi kawasan sebagai kawasan perbatasan antar negara.Pertumbuhan ekonomi dapat juga diketahui dari besarnya laju pertumbuhan ekonomi rata-rata dibandingkan dengan laju pertumbuhan penduduk (Arsyad, 2005). Dari hasil analisis yang dilakukan, laju pertumbuhan ekonomi rata-rata di Kecamatan Entikong mencapai angka
$5,88 \%$ yang lebih tinggi dari angka laju pertumbuhan penduduk, yaitu $1,18 \%$. Kondisi tersebut mencerminkan adanya pertumbuhan ekonomi, karena laju pertumbuhan ekonomi lebih tinggi dari laju pertumbuhan penduduk. Kontribusi ekonomi yang dimiliki oleh Kecamatan Entikong terhadap Kabupaten Sanggau rata-rata sebesar 2,32\% (tahun 2009-2013), dengan kondisi yang relatif menurun sejak tahun 2009. Menurunnya kontribusi ekonomi Kecamatan Entikong dalam mendukung perekonomian Kabupaten Sanggau cenderung menunjukkan stagnasi fungsi kawasan perbatasan Entikong yang seharusnya mampu menjadi pusat pertumbuhan bagi kawasan sekitarnya. Kondisi tersebut perlu dicermati dalam perkembangannya karena Kecamatan Entikong menjadi Pusat Kegiatan Strategis Nasional (PKSN) yang berperan penting, baik secara internal kawasan perbatasan maupun secara eksternal (Kabupaten Sanggau dan Kota Pontianak).

Dengan adanya PPLB, tingkat kesejahteraan masyarakat di kawasan perbatasan di Kecamatan Entikong sudah meningkat (khusus di wilayah tertentu yang dekat dengan akses PPLB), namun tidak merata di seluruh hinterland perbatasan, fenomena tersebut direspon oleh pemerintah dengan pembangunan infrastruktur di wilayah hinterland agar memudahkan akses menuju PPLB (belum terlaksana). 
154 | Kardius Richi Yosada, Analisis Pertumbuhan Ekonomi dan Pengembangan Wilayah

Kondisi pertumbuhan ekonomi di Kecamatan Entikong tidak terlepas dari sektor basis yang berperan penting dalam perkembangan perekonomian, meskipun mengalami fluktuasi. Apabila dilihat dari konteks pertumbuhan ekonomi, berkurangnya peran sektor pertanian yang mengarah pada sektor pendukung lain seperti pengangkutan dan komunikasi menunjukkan adanya pertumbuhan ekonomi dalam suatu wilayah. Menurunnya peran sektor pertanian terlihat juga pada analisis shift-share yang mengindikasikan kinerja sektor dalam perekonomian wilayah dan identifikasi sektor prioritas dari gabungan antara LQ dan Shift-Share.Sektor pertanian tergolong mundur dengan nilai pergeseran yang minus (KPP dan KPPW). Sejalan dengan analisis LQ, ternyata dalam analisis kinerja perekonomian, sektor pengangkutan dan komunikasi, listrik, gas dan air minum, jasa-jasa memiliki kinerja perekonomian yang maju.

Setiap tahun departemen custom pendapatan mencapai $15 \mathrm{M}$, belum dari imigrasi (pembuatan paspor) dan karantina (penentuan lolos/tidaknya barang yang diperdagangkan) artinya pendapatan yang sangat besar didapatkan di PPLB Entikong.

Terbukanya akses perbatasan Entikong terhadap pertumbuhan ekonomi di wilayah tersebut memiliki implikasi yang baik terhadap peningkatan kesejahteraan masyarakat, namun berbanding terbalik dengan implikasinya terhadap pemerintah daerah, karena pihak yang berperan dalam pengelolaan perbatasan tersebut adalah pemerintah pusat (Bea Cukai, Imigrasi), sehingga praktis penerimaan dari PPLB mengalir ke pusat. Dalam hal pertumbuhan ekonomi kawasan perbatasan, perubahan tersebut terjadi di Entikong, namun sangat lambat dan cenderung tidak berkontribusi terhadap perkembangan sebuah kawasan perbatasan.

Perkembangan terbaru dengan adanya peraturan Menperindag yang intinya hanya 5 pintu pelabuhan yang boleh melakukan kegiatan ekspor-impor, dimana Entikong tidak termasuk dalam pelabuhan tersebut.

Keberadaan PPLB Kecamatan Entikong tidak berkontribusi bagi daerah propinsi/kabupaten karena pendapatan mengalir ke pusat dan tidak ada sharring untuk daerah perbatasan.

Peran kebijakan yang sangat sensitif bagi pertumbuhan ekonomi di perbatasan Kecamatan Entikong merupakan halangan (barrier) yang membatasi pertumbuhan itu sendiri.Pertumbuhan ekonomi di kawasan perbatasan Kecamatan Entikong sangat tergantung pada kebijakan pusat dan kebijakan bilateral (tanpa melibatkan pusat) yaitu adanya forum Sosek Malindo. Dengan demikian, diperlukan adanya iklim yang kondusif dalam pertumbuhan ekonomi, termasuk penyiapan kebijakan yang fit dengan kondisi perbatasan dan pengembangannya. 
Untuk itu, kebijakan yang ada sebaiknya menunjang kedua belah pihak, khususnya Kecamatan Entikong dengan potensi koneksitas yang tinggi dengan Serawak (ditunjukkan dengan berkembangnya sektor tersier sebagai sektor prioritas, seperti pengangkutan dan komunikasi, jasa-jasa) untuk mengembangkan perekonomian dan mampu mengembangkan dirinya sebagai pusat pertumbuhan. Potensi kebocoran ekonomi (leakage) yang menyebabkan terganggunya pertumbuhan ekonomi dipengaruhi juga oleh kondisi infrastruktur yang belum menjangkau hinterland kawasan perbatasan.Kondisi ini sangat memungkinkan bagi mengalirnya sumber daya secara informal (ilegal) di wilayah perbatasan yang jauh, karena sulitnya menjangkau PPLB Entikong.

Kendala dalam pemanfaatan potensi yang ada di hinterland kawasan perbatasan Entikong adalah penyiapan infrastruktur bagi wilayah-wilayah tersebut menuju akses perbatasan (PPLB Entikong), karena penggunaan jalan tikus bagi ilegal trade sudah tidak memungkinkan karena dijaga oleh pasukan libas (Lintas Batas).

Dalam hal ilegal activity keberadaan border belum cukup mampu menangkal fenomena tersebut, interaksi sosial/ikatan sosial yang kuat di perbatasan menjadi salah satu penyebab dalam ilegal (logging, trafficking, fishing). Menurut Terminologi Wu (2001: 23), Entikong terlihat secara hubungan ekonomi dikontrol dengan ketat, infrastruktur yang masih rusak dan perbedaan kondisi sosial dan ekonomi antar wilayah yang berbatasan, sehingga masuk dalam kategori tipologiborder region. Kegiatan tersebut sudah bisa di tekan di pintu resmi, namun diakses perbatasan non resmi masih terus berjalan.

Pengembangan kawasan perbatasan yang terpadu dan menyeluruh seharusnya didukung oleh infrastruktur yang handal. Tanpa perencanaan dan pengembangan infrastruktur yang dapat menjangkau wilayah perbatasan, mustahil fungsi optimal sebuah kawasan perbatasan sebagai beranda negara dapat ditangani dengan baik.

Kondisi tersebut terjadi di perbatasan Entikong, perbedaan kondisi yang ada menyebabkan Malaysia menikmati semua keuntungan, karena praktis dari segala aspek lebih maju dan mampu menyediakan supply bagi masyarakat di Kecamatan Entikong.

Pada kasus Entikong, yang terjadi adalah ketergantungan yang sangat tinggi dengan pihak Malaysia, karena belum ada solusi untuk membuat produk yang bisa diekspor, sementara sebelum border dibuka sampai dengan sesudah dibuka, masyarakat selalu berorientasi untuk berbelanja ke seberang (alasan harga, kualitas, prosedur, birokrasi yang lebih murah dan lebih baik). Sementara itu di pihak Malaysia, birokrasi untuk partai kecil tidak begitu menyulitkan.

Perbedaan kondisi yang ada menyebabkan Malaysia menikmati semua 
156 | Kardius Richi Yosada, Analisis Pertumbuhan Ekonomi dan Pengembangan Wilayah

keuntungan, karena praktis dari segala menyediakan supply bagi masyarakat di aspek mereka lebih maju dan mampu Kecamatan Entikong

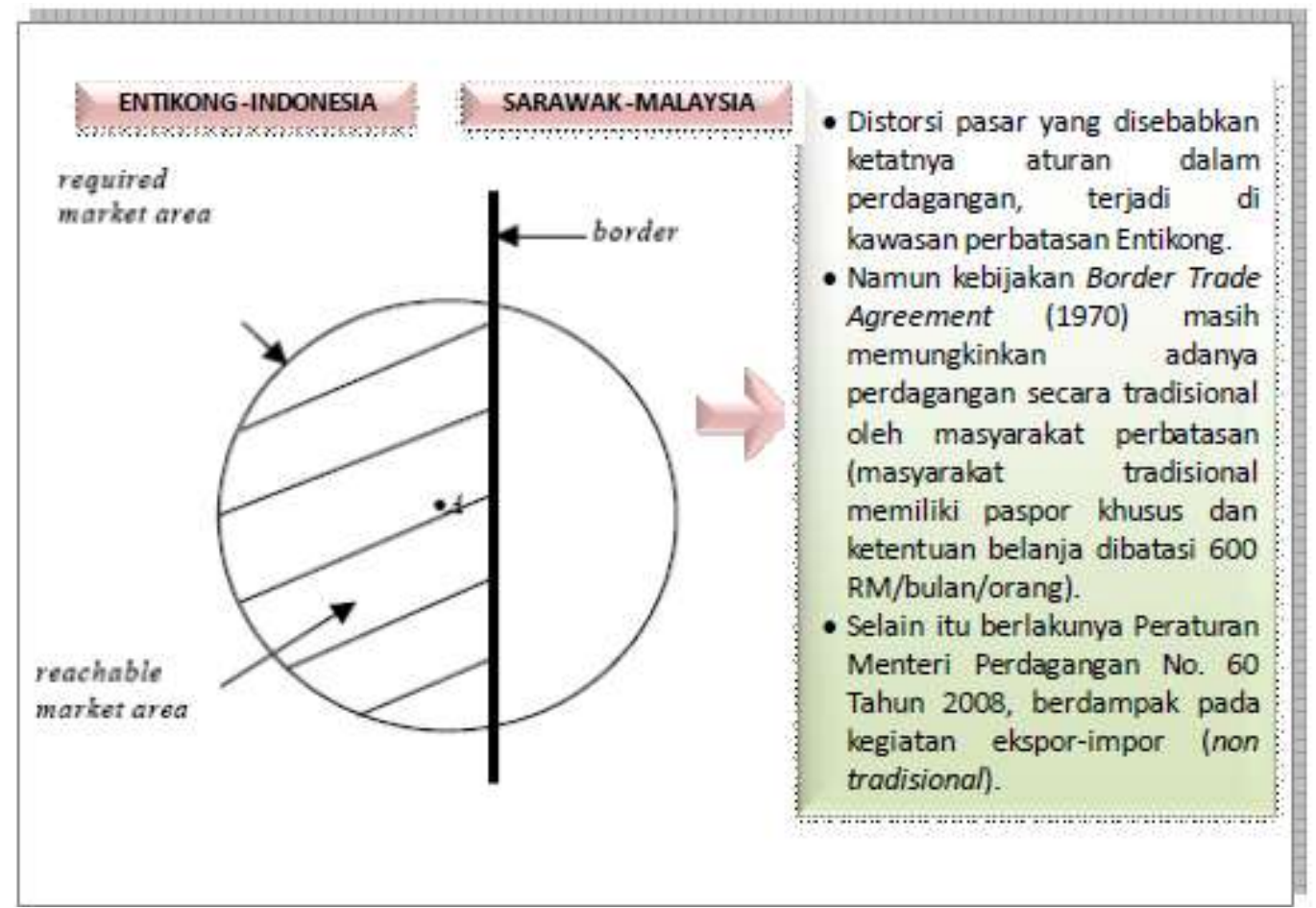

Sumber: Diadopsi dari Niebuhr dan Stiller, 2001

Gambar 1 Distorsi Pasar di Kawasan Perbatasan Entikong Yang Menjadi Barrier Dalam Pertumbuhan Ekonomi 


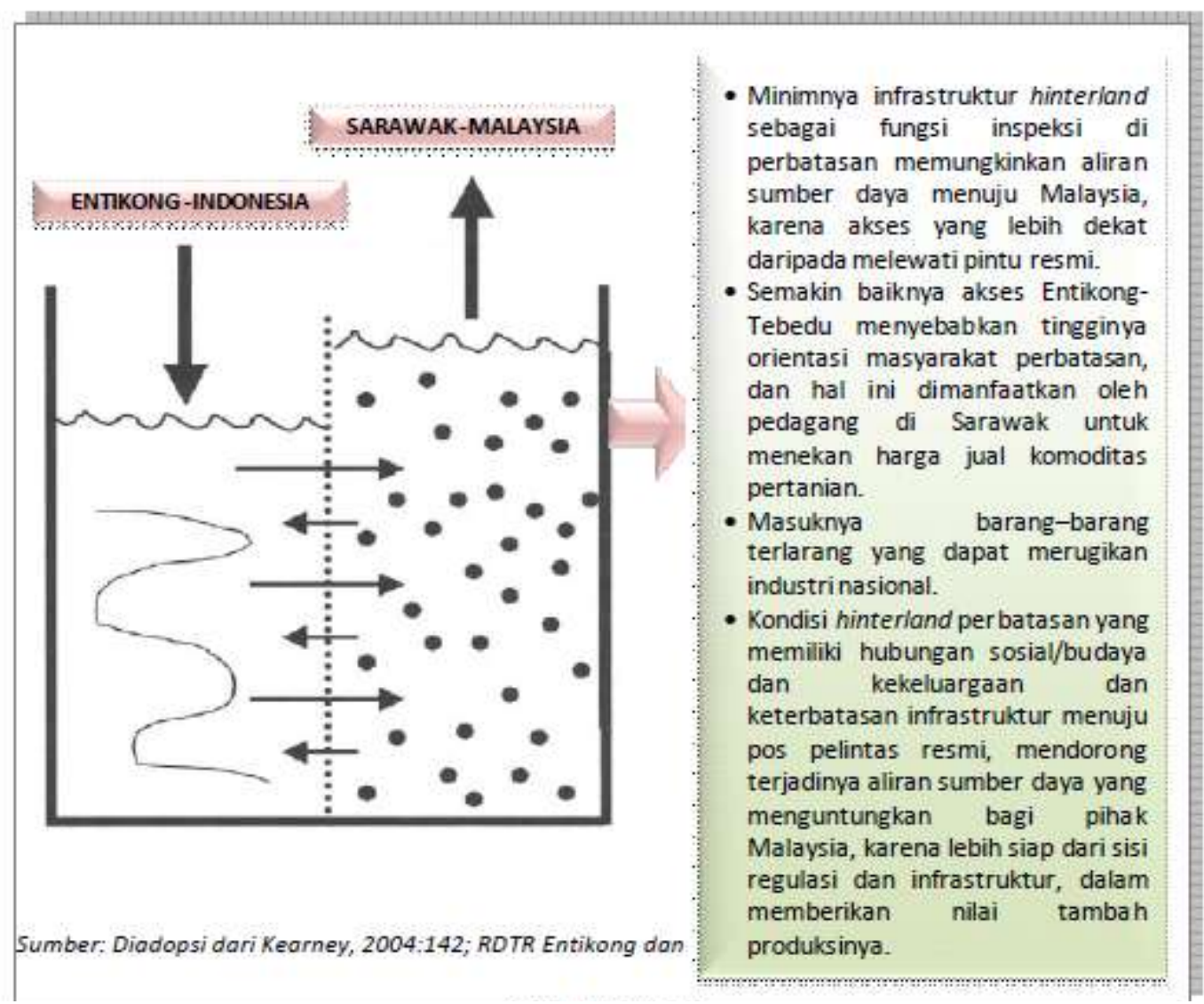

Gambar 2

Konsep Osmosis Dalam Pergerakan Aliran Perekonomian di Perbatasan Kecamatan Entikong

Kondisi di atas menjelaskan adanya limitasi dalam pertumbuhan ekonomi di kawasan perbatasan Kecamatan Entikong.Peran kebijakan pusat di kawasan perbatasan sangat penting dalam kontribusinya terhadap pengembangan kawasan perbatasan, khususnya di sisi ekonomi. Upaya pembangunan Kecamatan Entikong sebagai Pusat Kegiatan Strategis Nasional (PKSN) dan dukungan kebijakan regional (RTRW) sebagai Border Development Centre, atau sebagai pusat pertumbuhan akan menghadapi kesulitan apabila dihadapkan pada Peraturan Menteri Perdagangan Nomor 60 Tahun 2008, karena PPLB Entikong tidak lagi menjadi pelabuhan ekspor-impor (Dendy Kurniadi, 2009). Dengan adanya peraturan tersebut praktis hanya perdagangan oleh masyarakat perbatasan yang dapat dilakukan.Berbagai fisilitas yang sudah dirintis pemerintah, (Free Trade Zone, Dry Port, Balai Latihan Kerja, Rusunawa) diperkirakan tidak optimal karena adanya kebijakan tersebut.

Keterkaitan antar sektor mengarah pada kondisi yang lebih baik, dengan perkembangan yang paling baik pada sektor perdagangan, namun sekali lagi perkembangannya akan terbentur oleh peraturan menperindag (tentang lima pelabuhan yang akan melakukan ekspor-impor) akibatnya beberapa 
158 | Kardius Richi Yosada, Analisis Pertumbuhan Ekonomi dan Pengembangan Wilayah

kegiatan yang sudah direncanakan oleh pusat dan daerah bagi pengembangan perbatasan Entikong seperti pasar, rusunawa, Balai Latihan Kerja (BLK), pesimis untuk berkembang dan memberikan dampak yang positif bagi pertumbuhan ekonomi.

Dari hasil analisis yang dilakukan, terlihat pertumbuhan ekonomi yang terjadi di kawasan perbatasan Entikong belum menunjukkan peran kawasan dalam mendorong kawasan sekitarnya yang tercermin dari minimnya infrastruktur yang menghubungkan antar kawasan dan konsentrasi pembangunan hanya pada lokasi tertentu (Desa Entikong) yang merupakan lokasi PPLB. Dari lima (5) desa yang ada di Kecamatan Entikong, empat (4) diantaranya berbatasan langsung dengan Serawak, namun koneksitas antar wilayah tersebut relatif belum baik (akses infrastruktur jalan masih jalan tanah) dan kebutuhan energi listrik yang masih menjadi masalah di Kecamatan Entikong.

Salah satu masalah yang pelik di Kecamatan Entikong adalah listrik yang tidak dapat dipenuhi oleh Entikong, dimana hal ini menjadi penyebab bagi mundurnya potensi investasi, kendala ini akhirnya diatasi dengan membeli listrik dari Malaysia yang notabene menjadi polemik yang cukup berarti bagi keberlanjutannya akibat kecenderungan kondisi kedua negara yang relatif bergejolak.

Kegiatan perdagangan masyarakat tradisional dilakukan sejak Border Trade
Agreement (BTA) tahun 1970, sebesar 600 RM/bulan/orang, saat ini Forum Kerjasama Sosek Malindo sedang mengupayakan kenaikan sebesar 1500 RM/bulan/orang karena pertimbangan kurs dan kebutuhan masyarakat perbatasan.

\section{PENUTUP}

Pertumbuhan ekonomi yang terjadi di kawasan perbatasan Entikong belum menunjukkan peran kawasan dalam mendorong kawasan sekitarnya yang tercermin dari minimnya infrastruktur yang menghubungkan antar kawasan dan konsentrasi pembangunan hanya pada lokasi tertentu (Desa Entikong) yang merupakan lokasi PPLB. Dari lima (5) desa yang ada di Kecamatan Entikong, empat (4) diantaranya berbatasan langsung dengan Serawak, namun koneksitas antar wilayah tersebut relatif belum baik (akses infrastruktur jalan masih jalan tanah) dan kebutuhan energi listrik yang masih menjadi masalah di Kecamatan Entikong

\section{DAFTAR PUSTAKA}

Alkadri, Muchdie dan Suhandojo. 1999. Tiga Pilar Pengembangan Wilayah: Sumberdaya Alam, Sumberdaya Manusia, Teknologi. Jakarta: Pusat Pengembangan Kebijakan Teknologi Pengembangan Wilayah-BPPT Press

Badan Nasional Pengelolaan Perbatasan. 2010. Desain Besar Pengelolaan Batas Wilayah Negara dan 
Kawasan Perbatasan Tahun 2011-2025. Jakarta: BNPP.

Dimyati, M. 2004. Belajar Meneliti Secara Kualitatif Siapa Takut. Malang: Diterbitkan oleh Program Pascasarjana Fakultas Ilmu Pendidikan Universitas Negeri Malang.

Dinas Permukiman dan Prasarana Wilayah Kabupaten Sanggau 2014.

Hamid. et.al. (eds). 2003. Kawasan Perbatasan Kalimantan: Permasalahan dan Konsep Pengembangan. Jakarta: Pusat Pengembangan Kebijakan Teknologi Pengembangan Wilayah-BPPT Press.

Hamidi. 2005. Metode Penelitian Kualitatif. Malang: Penerbit Universitas Muhammadiyah.

Huberman, A.M and Milles, M.B. 1987. Qualitative Data Analysis A Sourcebook of New Methods, London New Delhi, Sage Publications.

__ 1992. Analisis Data Kualitatif. Jakarta: Penerbit Universitas Indonesia Press.

Kabupaten Sanggau Dalam Angka. 2013. Badan Pusat Statistik.

Kecamatan Entikong Dalam Angka. 2012. Badan Pusat Statistik.

Kompas. 2003. Indonesia Bangsaku, Ringgit Uangku. 21 Maret 2003.

Lembaga Administrasi Negara. 2004. Kajian Manajemen Kawasan Perbatasan Negara. Laporan Penelitian, Pusat Kajian Administrasi Internasional. Jakarta: Lembaga Administrasi Negara.
Mulyana, Agung. 2012. Kebijakan Umum dan Strategi Pengembangan Kawasan Perbatasan. Presentasi dalam Diskusi Masalah, Kebijakan, dan Program Pembangunan Kawasan Perbatasan Negara. Jakarta: Badan Nasional Pengelola Perbatasan.

Badan Persiapan Pengembangan Kawasan Khusus Perbatasan (BP2KKP) Propinsi Kalimantan Barat. 2008. Potensi dan Permasalahan Obyek Wisata Kawasan Perbatasan Antar Negara di Propinsi Kalimantan Barat. Profil Kecamatan Entikong 2014.

Riyadi, D.S. 2002. Dampak Globalisasi Ekonomi dan Kebijakan Regionalisasi Terhadap Pngembangan Wilayah Indonesia. Dalam Ambardi, M.U dan Prihawantoro, S. (eds). Pengembangan Wilayah dan Otonomi Daerah (pp.3-23). Jakarta: BPPT.

Taufik, Tatang.A. 2005. Penguatan Daya Saing Dengan Platform Klaster Industri: Prasyarat Memasuki Ekonomi Modern. Makalah disampaikan pada Seminar dan Lokakarya Nasional Strategi dan Implementasi Pengembangan Daya Saing Ekonomi Daerah Dengan Pendekatan Lintas Sektoral. Yogyakarta, 7-9 Pebruari 2005.

Undang-Undang Republik Indonesia Nomor 32 Tahun 2004. Tentang Pemerintahan daerah.

Undang-Undang Republik Indonesia Nomor 43 Tahun 2008. Tentang Wilayah Negara. 